\title{
Studying the Ecological Benefits of Spartina Grass Species and Use of a Mathematical Model (Pick's Theorem) for Historical Documentation and Future Restoration of Hypoxic Marshlands
}

\author{
Natalie Bush', Edward Bush'2, Pamela Blanchard', Nathan Bush4, Jennifer Conover5 \\ ${ }^{1}$ St. Joseph's Academy, Baton Rouge, USA \\ ${ }^{2}$ LSU AgCenter, Baton Rouge, USA \\ ${ }^{3}$ LSU College of Human Sciences and Education, Baton Rouge, USA \\ ${ }^{4}$ Department of Mathematics, Texas A\&M University, College Station, USA \\ ${ }^{5}$ Louisiana Universities Marine Consortium, Chauvin, USA \\ Email: thebushes1@cox.net
}

Received 8 September 2015; accepted 23 November 2015; published 26 November 2015

Copyright (C) 2015 by authors and Scientific Research Publishing Inc.

This work is licensed under the Creative Commons Attribution International License (CC BY). http://creativecommons.org/licenses/by/4.0/

C) (i) Open Access

\begin{abstract}
Coastal erosion, subsidence, salt water intrusion, and hypoxia are forces that impact Louisiana and beyond. The objective of this research was to determine the extent of land loss due to erosion and establish the best Spartina (S.) species to ameliorate the coast. Using graph theory in the Geometer's Sketch Pad program, progressive land loss from Isles Dernieres was determined from 1853 to 2005. This was accomplished using Pick's Theorem $(A=I+B / 2-1)$, where $A=$ total land area, $I=$ interior intersections, and $B=$ boundary intersections. The analysis indicated that there had been more than ninety percent land loss from 1853 to 2005 . Additionally, four plants from each Spartina species (alterniflora, patens, and spartinae) were planted and flooded in four containers, respectively, filled with potting soil, and a non-vegetated control was included in this same manner. Dissolved oxygen was measured three times a week under three different temperature regimes, twenty-two, thirty, and ten degrees Celsius, respectively. This resulted in the control group diffusing the most oxygen at twenty-two degrees Celsius, the $S$. alterniflora diffusing the most oxygen at thirty degrees Celsius, and all the species diffusing statistically similar oxygen levels at ten degrees Celsius. After six months of flooded conditions, penetration and subsidence were measured. The vegetated soils required the greatest penetration forces and subsided the least. Oxygen diffusion is dependent on plant species and temperature. The penetration and sub-

How to cite this paper: Bush, N., Bush, E., Blanchard, P., Bush, N. and Conover, J. (2015) Studying the Ecological Benefits of Spartina Grass Species and Use of a Mathematical Model (Pick's Theorem) for Historical Documentation and Future Restoration of Hypoxic Marshlands. Journal of Water Resource and Protection, 7, 1363-1374.
\end{abstract}

http://dx.doi.org/10.4236/jwarp.2015.716110 
sidence results also support the conclusion that plants can reduce land loss and preserve the coastline.

\title{
Keywords
}

\author{
Coastal Restoration, Phytoremediation, Barrier Island Mitigation, Land Subsidence
}

\section{Introduction}

Coastal erosion is a serious problem in Louisiana causing significant economic and land loss. Louisiana's coastal infrastructure is worth more than $\$ 150$ billion in value. The commercial fisheries in Louisiana provide $25 \%$ to $35 \%$ of the nation's entire catch. These southern fishermen are first in the yearly harvest of shrimp (Penaeus sp.), crabs (Callinectes sapidus), oysters (Crassostrea virginica), red snapper (Lutjanus campechanus), crawfish (Procambarus clarkii), wild catfish (Siluriformes), mullet (Mugilidae), and sea trout (Salmotrutta). Fisheries account for an estimated 3.1 billion dollar impact to Louisiana in 2009. By 2050, it is predicted that the commercial fish industry will decrease by $\$ 550$ million and the loss for recreational fisheries will be about $\$ 200$ million a year [1]. Twenty-five percent of the energy supply in the United States is dependent on facilities in Louisiana. The oil and gas companies in Louisiana have a net value over $\$ 16$ billion a year. Twenty thousand miles of pipes run through federal lands offshore and many more are inland. The wetlands serve as protection for pipes from waves and secure the pipelines in place. As wave action deteriorates land, more pipelines are exposed increasing the risk of shipping traffic being disrupted. Louisiana is the first in the nation for total shipping weight, so channeling occurs often in order to allow the large cargo to pass through successfully. Saltwater intrusion as a result of channelization destroys wetland plants, contributing to the loss of habitats for wildlife. It is estimated that at the current rate of land loss more than 155 miles of waterways and several of the ports will be exposed to open water within fifty years [1]. Erosion] is defined as land loss caused by natural forces including water, waves, ice, wind, or tide [2]. If erosion continues at the current rate continue, approximately 640,000 more acres of Louisiana's land will be submerged by the year 2050 [3]. The impacted land area is approximately the size of the state of Rhode Island. Land subsidence, erosion, and sea level rise are the major contributing factors to land loss. The coast supports important infrastructure like ports, pipelines, navigational waterways, and highways which all hold financial significance. The importance of Louisiana's coast has worldwide ecological significance affecting the abundance of fisheries, wildlife and waterfowl, and impacting a critical migratory flyway [3]. If current rates of erosion and subsidence continue, the wetland loss in Louisiana alone can cost the nation $\$ 36$ billion in the next 50 years [3].

Land subsidence occurs naturally or as a result of human activities due to organic substrates decomposing without replenishment in coastal and developed areas. Subsidence impacted 17,000 square miles in the United States [4]. Oxidation is one major cause of subsidence because plant tissue organic carbon is converted to water and carbon dioxide gas. The loss of organic matter causes the land to collapse [4]. Much of the national land subsidence occurs due to the exploitation of groundwater. With the rate of subsidence increasing, land elevations decrease in elevation and eventually become fully submerged by water and unable to sustain life. Subsidence has become a major issue in Louisiana, causing a continuous loss of land [5].

Louisiana's coastal management requires a deep knowledge of factors that influence land change over time [6]. Quantifying coastal land loss is essential for historical documentation and restoration of eroding barrier islands. The irregular shape of deposited barrier islands and marshlands is frequently in the shape of complex polygons. Pick's Theorem is a simple mathematical method used to determine the areas of complex and non-convex polygons. Pick's Theorem is defined as $A=I+B / 2-1$, where $A$ is the total area, $I$ is the number of intersection points on the interior, and $B$ is the number of intersection points on the boundary. A plane is tiled into 1:1 ratio squares and if shifted one unit north, south, east, or west, it will finish its position on another square. Each intersection point is used in the formula whether included on the border or interior of a polygon [7]. A land owner in Oregon used Pick's Theorem to calculate the approximate size of his forest. To approximate the area, dots in the interior of the polygon were added to half the amount of dots on the boundary and multiplied this sum by the factor of scaling [7]. This mathematical theorem is well suited to the irregular shapes of barrier isl- 
ands.

A barrier island is defined as a long, narrow coastal island, separated from the mainland by a shallow water lagoon or marsh [2]. Barrier islands are areas of sandy land located by a shore that consist of environments including: dunes, marshes, coastal flats, and swales. Barrier islands support diverse marine and plant life and buffer wave energy from the storms; however, the barrier islands are typically low-lying, making them susceptible to flooding. These islands are incessantly changing position and location, moved by currents, waves, and tides [8]. The Louisiana barrier islands were created by the Mississippi River's delta. Settlements on the islands have been abandoned due to erosion and exposure to storms. Grand Isle is the only Louisiana barrier island in Louisiana that still contains a settlement. These front-line islands endure the strongest impact from any storm, buffering the damaging forces from populated areas [8]. Barrier islands serve as a crucial ecosystem for wildlife and serve as nesting habitats for birds. The aquatic environments adjacent to land provide sustenance and socioeconomic benefits. Barrier islands are essential for the protection of Louisiana's resources and communities [8]. The barrier islands and wetlands serve as protection from hurricanes and heavy winds. Every 14,256 feet of wetlands will be inundated by $30.48 \mathrm{~cm}$ (12 inches) of a storm surge. The loss of each one-mile strip of land on the coast costs an estimated $\$ 5,752,816$ more every year. About $65 \%$ of Louisiana's population dwells on the coast or within fifty miles. These 2,000,000 people are left exposed to dangerous winds and hurricanes without the barrier islands and marshes [1].

The Isle Derniere islands $\left(29^{\circ} 02^{\prime} 19^{\prime \prime} \mathrm{N}, 90^{\circ} 48^{\prime} 15^{\prime \prime} \mathrm{W}\right)$, also known as Last Islands(English translation), are a specific group of barrier islands located in the Gulf of Mexico between Caillou Bay and Lake Pelto and are made up of the following islands: Whiskey, Trinity, East, Raccoon, and Wine (or Vine). The closest village to the islands is Cocodrie, located thirteen miles northeast of Trinity Island. This island served as the "first line of defense" for the land behind it. It is estimated that in $1300 \mathrm{AD}$, Last Island formed from soft mud flats and high grasses [9]. The Mississippi River gradually deposited sediment until it was not an efficient path. Then, erosion began which released sand and mud into the Gulf. The geology of Louisiana's coastal zone is intrinsically linked to the history of the Mississippi River [6]. The sandy region formed into a long arc over time, and formed a sandy area known as Isle Derniere (French) in the 1800s. Island Derniere was originally a resort island with white beaches, clearer water than the marshy mainland, and constant breezes [9]. A hurricane on August 10, 1856 severely damaged Isle Derniere and completely inundated the island with its storm surge. Sallenger [9] remarked that after the 1856 hurricane, Isle Derniere had been pushed beyond a tipping point from which it could not recover. The hurricane killed two-hundred people, around half the population on the island. Every structure on the island was destroyed, and the named changed from a singular 24 mile island, to plural, Isles Dernieres, since the island had separated into two smaller islands. Today, after additional storms, eroding, and subsidence, the once whole island is now segmented. This massive storm denuded the island of vegetation which effectively is essential for the stabilization of sand and providing shelter and food for organisms. Wetland plants also provide habitat and oxygen, another necessity for organisms. Today the fragmented Isle Derniere is a haven for seabirds like pelicans and other animals and plants [9]. The plants on barrier islands have adapted to the constantly changing environment with extensive root systems, photosynthesizing and releasing oxygen, and these tough leaves are able to withstand wind and salt. Several species of Spartina are commonly used on the coast due to their strong roots, adaptability to hypoxia, and high salt tolerance [8].

A major problem is that the Gulf of Mexico has dangerously low oxygen levels that occur each summer since oxygen diffusionis less in warm water. Biological indicators including algal blooms, fish swimming at the top of water for air or fish kills serve as a clue to dead zones. This hypoxicregion is called the dead zone. The dead zone is predicted to be 5840 miles this year. The dead zone is caused when nutrients from fertilizer runoff and soil erosion flow into the Gulf proliferating small organisms. After dissolved oxygen levels become anoxic organisms begin to die resulting in a dead zone. The decomposition of organisms requires increased oxygen demand [10]. Wastewater treatment facilities use tertiary water treatment to reduce nutrient loads. Wastewater is passed through man-made marshes so that plants can assimilate available nutrients. Another cause of Gulf of Mexico dead zones is a lack of storm activity or windy weather which would blend normoxic and hypoxic water. Hypoxic water eventually becomes anoxic when oxygen demand is increased, where it cannot support marine life. Reducing the dead zone could be achieved by using water diversions sent from the Mississippi River through marsh areas which could decrease the waste nutrients that are typically deposited into the Gulf of Mexico [10]. Any damage done to wetland habitats can greatly decrease the quantity and diversity of living organisms that are dependent on these areas for shelter and sustenance. Louisiana marshes commonly serve as nurseries for organ- 
isms that are financially significant for the economy like shrimp, crabs, and redfish (Sebastes fasciatus). Barrier islands are gradually segmented causing a spike in shrimp populations. More area on the shoreline, also called land-water interface, is available for organisms to sustain themselves. Although it seems counter-intuitive, an increase in shrimp harvests could actually be a warning sign of past and future land loss. This concept is clearly demonstrated in an activity developed by Blanchard [11] which explains the importance of coastlines to shrimp populations. Eventually, the size of the marshes decreases as a result of erosion and subsidence, until the island cannot sustain the food web.

Shrimp move into estuarine nursery areas and feed at the vegetation (marsh grass, mangrove, or seagrass) water interface [12]. Post larvae shrimp from 25 to $44 \mathrm{~mm}$ indiscriminately ingest the top layer of sediment, which is primarily comprised of Spartina, algae, and microorganisms. The health of a marsh impacts the productivity of Louisiana's estuaries and bays [11]. As living organisms decline, the perimeter increases as erosion begins, until it is fully eroded at which point it is too late to reverse [11].

The genus Spartina (S.) (S. alterniflora, S. spartinae and S. patens) is uniquely adapted to live in the harsh Louisiana Gulf of Mexico coastline. Spartina alterniflora, also known as smooth cordgrass or oystergrass, is used along salt marshes particularly for coastal restoration of levees, shores, canal banks, and other places where soil and water meet. Grass plants stabilize soil effectively in places that are loosely packed and can tolerate up to 33 ppt salinity. Spartina alterniflora are typically $60.96 \mathrm{~cm}$ (24 inches) to $213.36 \mathrm{~cm}$ (84 inches) in height with a typical leaf blade. They are long-lived perennials that thrive in the warm seasons. Smooth cordgrass normally grows continuously and parallel to shorelines. Spartina alterniflora is primarily propagated using division. The circulation of water around this grass impacts its strength as well as the amount of debris or multitude of herbivores in the area [13]. Spartina spartinae grass, commonly known as gulf cordgrass, work effectively with projects that pertain to coastal restoration. These plants can serve as habitats for birds and a source for the forage of cattle and geese. Plant leaves are stout, thickly clumped, and flowered in spring and summer. Spartina spartinae grows on the Gulf Coast from Texas to Florida and also grows into Eastern Mexico. These grasses require very little maintenance and are fairly tolerant to drought. The durability of this grass makes it a practical grass to aid coastal restoration [14]. Spartina patens grasses, also referred to as salt meadow cordgrass, are also used for coastal restoration to stabilize levees and dunes by beaches or on barrier islands. They provide food and shelter to many species of wildlife and are commonly used in areas with loose soil. These grasses normally grow from $30.48 \mathrm{~cm}$ (12 inches) to $121.92 \mathrm{~cm}$ (48 inches) tall and have shiny, dark green leaves. Spartina patens are found growing within marshes containing salt or brackish conditions, dunes of low elevation, sandy beaches, and tidal flats. They commonly grow along the coast of the Gulf of Mexico and on the Great Lakes' shores. These marsh grasses have a high tolerance for salinity [15].

Land subsidence, erosion, sea level rise, and human activities are major contributing factors to land loss. Saltwater intrusion as a result of channelization kills large areas of plants contributing to the loss of habitats for wildlife. In addition to high salinity, hypoxic and anoxic areas are deadly to organisms but can be aided by an increase in vegetation [16]. Determining the species of Spartina that diffuses the most oxygen into water can assist with management of negative hypoxic and anoxic effects. When oxygen levels are increased, organisms are able to survive and preserve habitats. Erosion can still occur, but marine organisms along the shoreline can lessen their effects [8]. Louisiana's marshes and barrier islands serve as part of our storm defenses, a vital and productive ecosystem that buffers from the impact of tropical storms and hurricanes [1]. These marshes are critically endangered by subsidence, erosion, salt water intrusion and pollution. Without restoration efforts, The Isle Derniere Islands are predicted to disappear in the year 2033 [1].

The purpose of study one was to determine if Pick's Theorem is an accurate mathematical model tool to determine and partition historical land losses. Study two will determine the ecological benefits of Spartina species for the amelioration of hypoxic marshlands.

\section{Materials and Methods}

United States Geological Survey maps of Isle Derniere Island depicting land masses in 1853, 1887, 1934, 1996, and 2005 were scanned into Geometry Sketch Pad. All maps of the islands were digitally traced on a grid, plotting the middle points, and applying the solutions to the formula to determine the perimeter, interior and total land area. Pick's Theorem, $A=I+B / 2-1$, was used to determine the change in land area of the Isle Derniere Islands over time. After each land area was calculated, the percent of change formula was used, Percent of 
Change $=$ Original - New/Original, to determine the change in land area over time.

Spartina plants (Spartina alterniflora, Spartina spartinae, and Spartina patens) were potted into four threegallon nursery root pruning basket pots filled with an organic potting soil. These socket pots were placed in a plastic lined nursery pot to allow for water logging to occur. These tight fitting pots were selected to reduce exogenous oxygen diffusion through exposed water surfaces. Plants were fertilized with $420 \mathrm{~g}$ of 15-9-11 Osmocote Plus 12 to 14 month release fertilizer. Plants were allowed to acclimate for 11 weeks before study initiation. Dissolved oxygen in water was measured using a calibrated Hanna HI 98186 dissolved oxygen/BOD/OUR/ SOUR Meter. One inch long 3/4" PVC pipe was wedged between the base and socket pots to measure DO. Plants were watered daily as needed. Data including plant height and width was measured every five weeks. At the end of the project, an Ele International G-128-29-3729 penetrometer $\left(\mathrm{kg} / \mathrm{cm}^{2}\right)$ was used to measure soil penetration force. Subsidence was determined by measuring the difference in the original soil line and the final soil level.

Spartina research plants were randomized and arranged in a RCBD. Data was collected each week and means statistically compared using a Duncan's Multiple Range Test. Plant tissue nutrient analysis (N, C/N ratio, P, K, $\mathrm{Ca}, \mathrm{Mg}, \mathrm{S}, \mathrm{B}, \mathrm{Cu}, \mathrm{Fe}, \mathrm{Mn}, \mathrm{Mo}$ and $\mathrm{Zn}$ ) was analyzed by the LSU Soil Testing Lab. Nutrient analysis was initiated by harvesting plants tops at the termination of the project, and dried at $60^{\circ} \mathrm{C}$. One gram of ground plant material was transferred into a $20 \mathrm{ml}$ scintillation vial and placed in an oven at $50^{\circ} \mathrm{C}$ for $1 \mathrm{~h}$ to remove residual moisture. Vials were transferred to desiccators for $1 \mathrm{~h}$ to further remove moisture and cool the sample to room temperature. The caps of each sample were tightened upon removal from the desiccators to prevent moisture from re-entering. Carbon and $\mathrm{N}$ tissue samples $(0.15 \mathrm{~g} / \mathrm{sample})$ were measured into tin foil cups and nitrogen (\% dry weight) was tested using a LECO TruSpec C/N Analyzer. The machine was calibrated using 5 NIST apple tissue samples and 5 blank samples. All other elements were analyzed by placing $0.5 \mathrm{~g}$ of tissue into a $50 \mathrm{ml}$ tube (SCP Scientific digiTUBE). Funnels were placed in each tube, and samples were placed into an automatic digester (Thomas Cain, DEENA) for digestion using nitric acid. During the digestion, the samples are heated for 6 $\mathrm{s}$ at $60^{\circ} \mathrm{C}$ and $2.2 \mathrm{ml}$ of distilled water is added. After $2 \mathrm{~m}, 5 \mathrm{ml}$ nitric acid (SCP Science, $67 \%$ to $70 \% \mathrm{HNO}_{3}$, reagent grade) was dispensed into each tube, and the temperature was increased $10^{\circ} \mathrm{C}$ every $10 \mathrm{~m}$ from $60^{\circ} \mathrm{C}$ to $110^{\circ} \mathrm{C}$. The temperature was increased to $125^{\circ} \mathrm{C}$ and held for $45 \mathrm{~m}$, and then held for $50 \mathrm{~m}$ at $128^{\circ} \mathrm{C}$, and cooled for $2 \mathrm{~m}$. One $\mathrm{ml}$ of hydrogen peroxide (Macron Fine chemicals, 30\% solution) was dispensed into each tube, cooled for $5 \mathrm{~m}$ and reheated for $5 \mathrm{~m}$ to $128^{\circ} \mathrm{C}$. One $\mathrm{ml}$ of hydrogen peroxide was dispensed, and another $1 \mathrm{ml}$ of hydrogen peroxide was dispensed into each tube. Samples were cooled for 5 minutes and heated for 30 minutes at $122^{\circ} \mathrm{C}$, cooled for 6 seconds to $20^{\circ} \mathrm{C}$ and cooled for 1 more minute. The volume of each sample was brought to $20 \mathrm{ml}$ using distilled water. Samples were removed from the digester and vacuum filtered using a 1.0 micron Teflon membrane filter (SCP Science) into another $20 \mathrm{ml}$ tube. ICP was performed for the elements $\mathrm{P}, \mathrm{K}, \mathrm{Ca}$, $\mathrm{Mg}, \mathrm{S}, \mathrm{Al}, \mathrm{B}, \mathrm{Cu}, \mathrm{Fe}, \mathrm{Mn}, \mathrm{Mo}, \mathrm{Na}$, and $\mathrm{Zn}$ using a Spectro Arcos according to the LSU Soil Testing and Plant Analysis Lab's AgMetals procedure. The instrument was calibrated using one blank and 6 standard samples. Samples were run in sets of 60 ( 2 blanks included) with two National Institute of Standards and Technology (NIST) peach samples and an internal standard every 20 samples. The data was verified to ensure it was within the tolerant ranges of the NIST and internal standards. Nutrient levels were reported as \% (dry weight) for macronutrients and ppm (mg/kg dry weight) for micronutrients.

\section{Results and Discussion}

Pick's theorem estimated the total area and perimeter areas of all maps studied (Maps 1-5). Additionally, data gained by this method can be used to compare interior, perimeter, and total area for documentation and future restoration efforts. When published land areas (1) were compared to calculated land areas, land areas were within $10 \%$ accuracy. A slight underestimation was expected since the islands are irregularly shaped. The 1853 is the earliest accessible map of Isle Derniere serving as a reference point for land area mathematical changes. Land mass changes between 1853 and 1887 indicated a 49\% loss in total land area. Data from Map 1 and personal accounts [17] of the destructive force of hurricanes and erosion exemplify the challenges of island preservation. Isle Dernieres land mass in 1934 continued to decrease by another $46 \%$. In relation to the land area in 1853 , the 1934 land area resulted in a 92\% loss. Perimeter measurements indicated a slight increase from 1887 to 1934 after erosion occurred; however, following 1934 the perimeter area steadily decreased from 1934 to 2005 [17]. The 1996 Isle Dernieres map provides a visual representation of the islands before massive restoration projects 


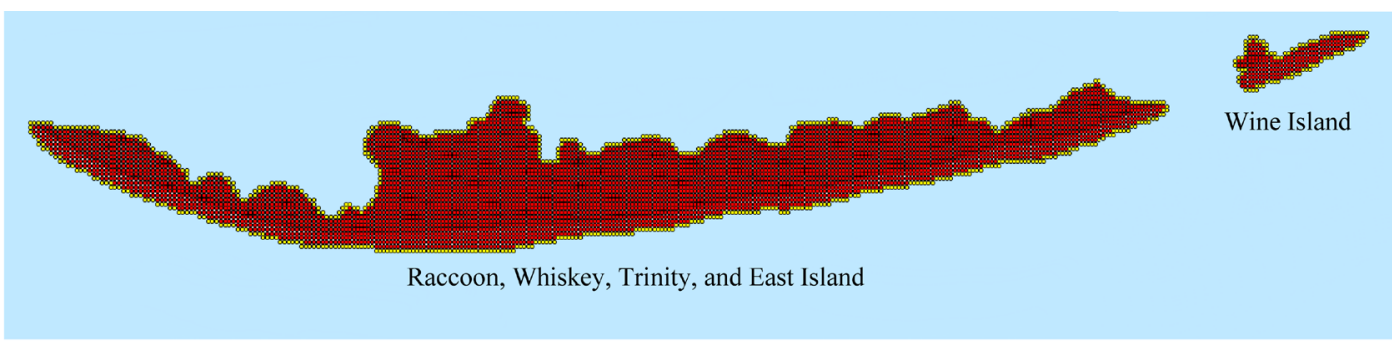

Map Key:

Yellow Dots $=$ Exterior Intersections

Calculated Land Area: $62.435 \mathrm{~km}^{2}$ (Bush, 2014)

Red Dots $=$ Interior Intersections

Map 1. Mathematical calculation of land area of the Isle Derniere Islands in 1853 using Pick's Theorem.

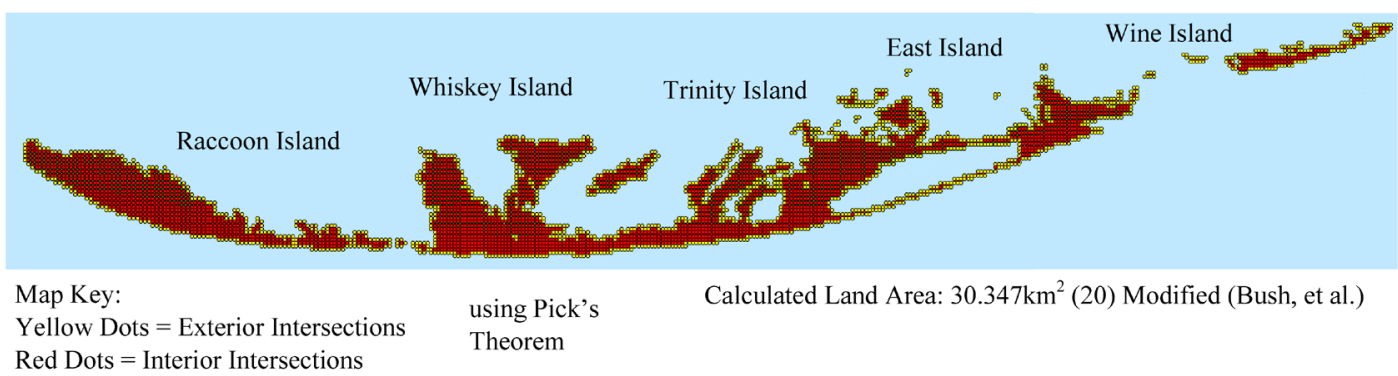

Map 2. Mathematical calculation of land area of the Isle Derniere Islands in 1887 using Pick's Theorem.

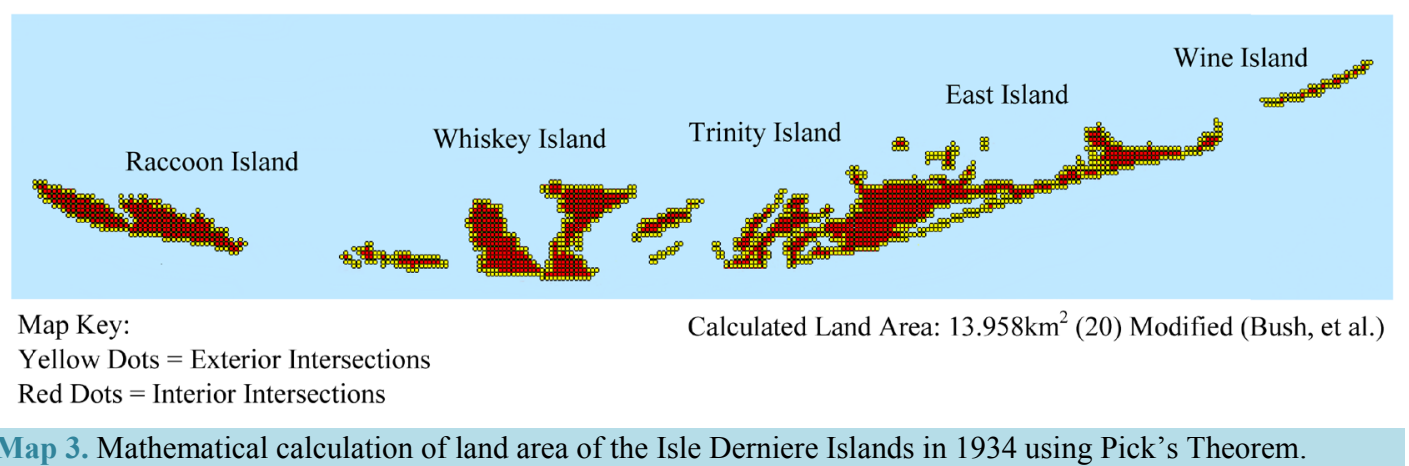

Map 3. Mathematical calculation of land area of the Isle Derniere Islands in 1934 using Pick's Theorem.

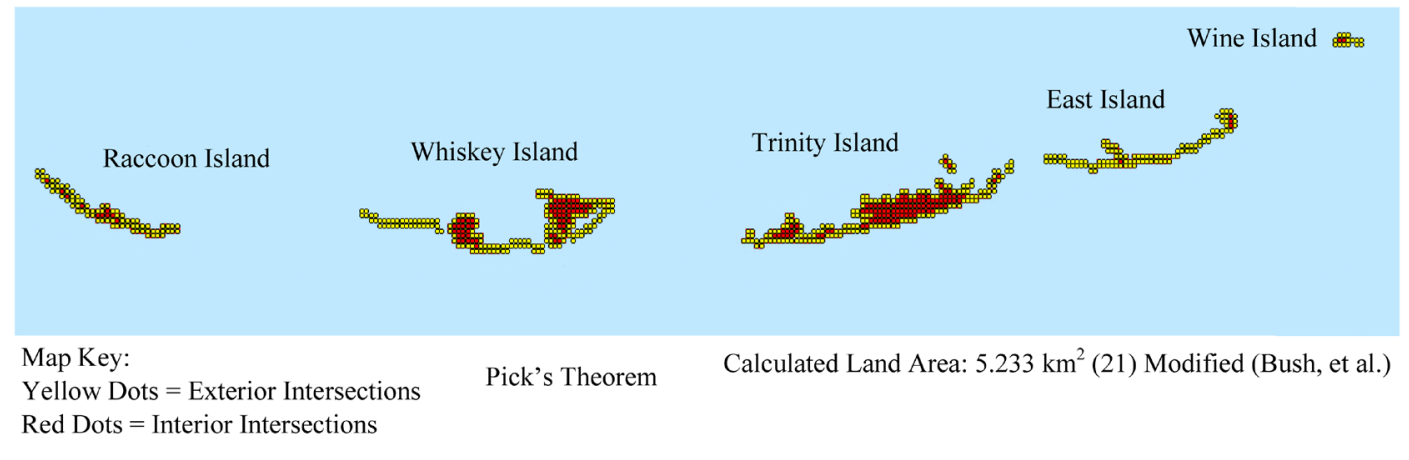

Map 4. Mathematical calculation of land area of the Isle Derniere Islands in 1996 using Pick's Theorem.

and hurricanes Katrina (2005) and Rita (2006) occurred. The land area calculated in this illustration represents a 92\% loss compared to 1853 (Graph 1). The 2005 map actually increased by 0.8 percent in spite of Hurricanes Katrina and Rita, and natural erosion and subsidence resulting from multiple restoration projects. Barrier Islands exist due to geological changes and erosion [18]. Documentation of land deposition and land loss can assist with 


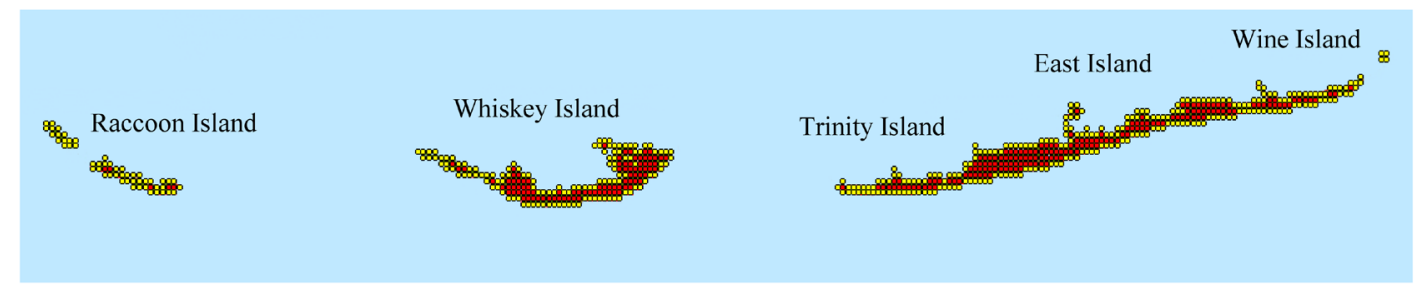

Map Key:

Calculated Land Area: $5.276 \mathrm{~km}^{2}$ (22) Modified (Bush, et al.)

Yellow Dots $=$ Exterior Intersections

Red Dots $=$ Interior Intersections

Map 5. Mathematical calculation of land area of the Isle Derniere Islands in 2005 using Pick's Theorem.

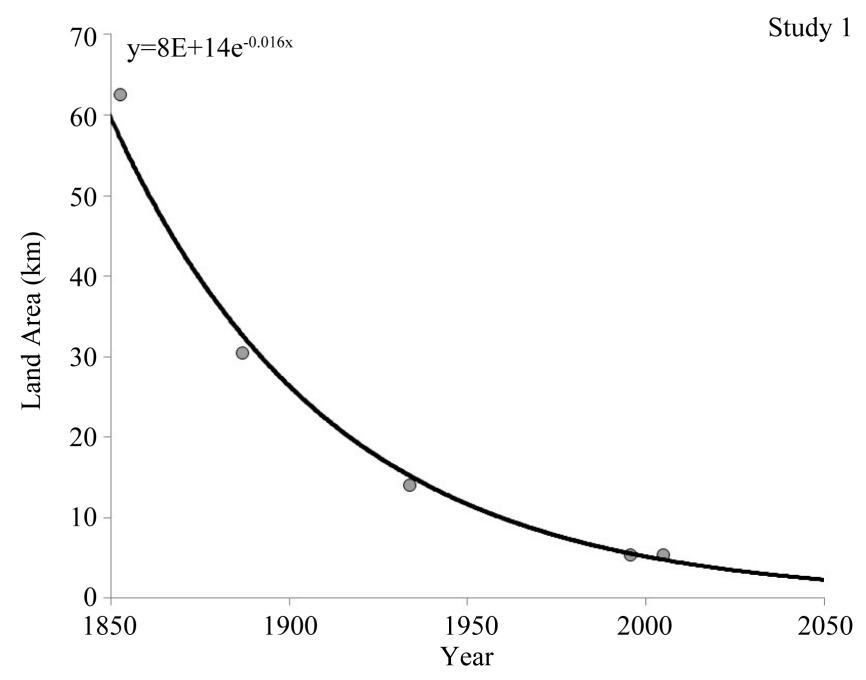

Graph 1. Best-fit exponential decay predication model of Isle Dernieres from 1853 to 2050 .

the management of these valuable resources.

Spartina's physiological adaptations are ideal for the harsh environment of coastal Louisiana. Their diffusion of oxygen in water under specified temperatures models their relationship with seasonal transitions and the variance of weather. The control dissolved oxygen (DO) level at $22^{\circ} \mathrm{C}$ was significantly greater than Spartina alterniflora, Spartina patens, and Spartina spartinae treatments (Figure 1). Spartina alterniflora maintained the greatest DO of the three grass species, and the Spartina spartinae diffused the least oxygen (Figure 1). At $30^{\circ} \mathrm{C}$, Spartina alterniflora grasses and the control maintained the highest DO levels; while the Spartina spartinae grasses maintained the least DO (Figure 2). The lowest DO levels were measured at $10^{\circ} \mathrm{C}$, however there were no significant differences measured between treatments (data not shown). At $10^{\circ} \mathrm{C}$, all measurements were below the detection range of the DO probe. The control maintained the highest DO at all specified temperatures compared to Spartina alterniflora, Spartina patens, and Spartina spartinae planted in containers. Spartina alterniflora diffused the most DO among the three species, and Spartina spartinae diffused the least. Physiological adaptations such as aerenchyma cells in the leaves, stems, and roots of the Spartina grasses that can exchange gasses in wetland plants are essential in combating hypoxia and anoxia. The maximum DO level was measured at $22^{\circ} \mathrm{C}$. The estimated optimal temperature for DO diffused by Spartina grasses in this study was $20.3^{\circ} \mathrm{C}$ (Figure 3).

Under waterlogged conditions, the control and Spartina alterniflora penetration forces were statistically similar; however, Spartina patens and Spartina spartinae penetration forces were greater (Figure 4). Drained soils from Spartina alterniflora, Spartina patens, and Spartina spartinae grasses required similar forces to penetrate their surfaces (Figure 5). Plant roots form a supportive matrix which aids soil stabilization. Additionally, these roots could both minimize erosion and help accumulate and stabilize sediment. The control soil had the greatest subsidence, as expected (Figure 6). Soils containing plants with established root systems required the greatest 


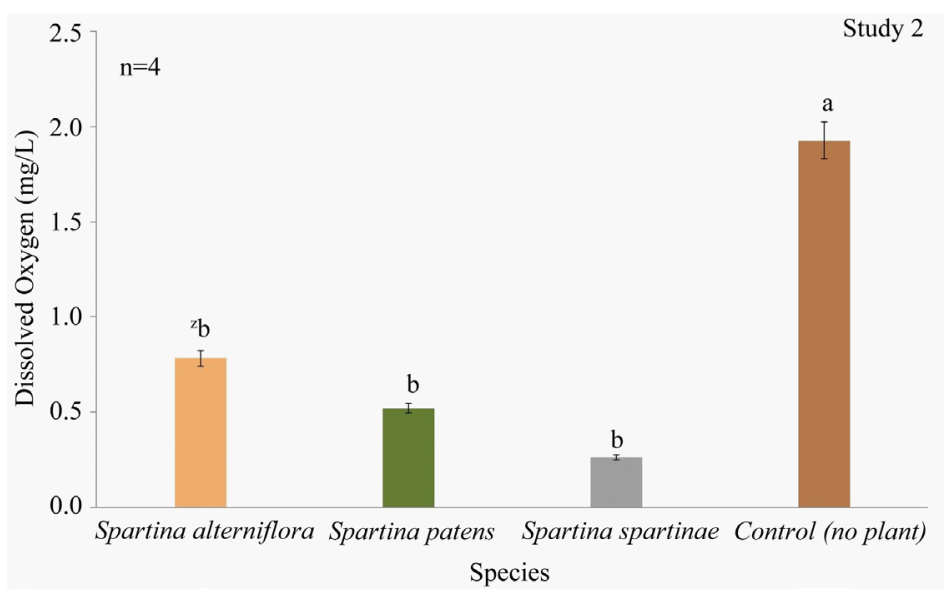

Figure 1. The effect of plant species on dissolved oxygen diffused in water at $22^{\circ} \mathrm{C}$. ${ }^{\mathrm{z}}$ Means with the same letter are not significantly different at the 0.05 level Vertical bars represent standard error.

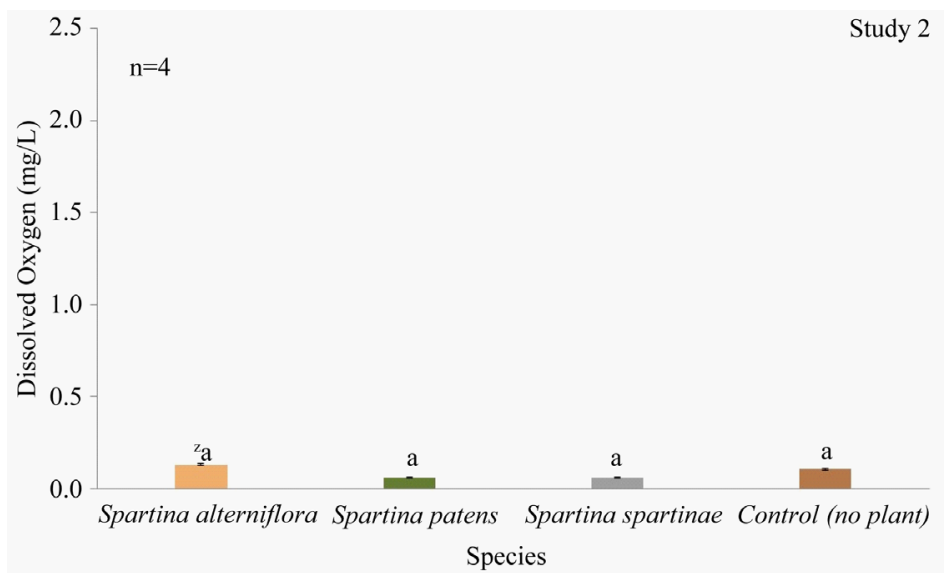

Figure 2. The effect of plant species on dissolved oxygen diffused in water at $30^{\circ} \mathrm{C}$. ${ }^{\mathrm{z}}$ Means with the same letter are not significantly different at the 0.05 level Vertical bars represent standard error.

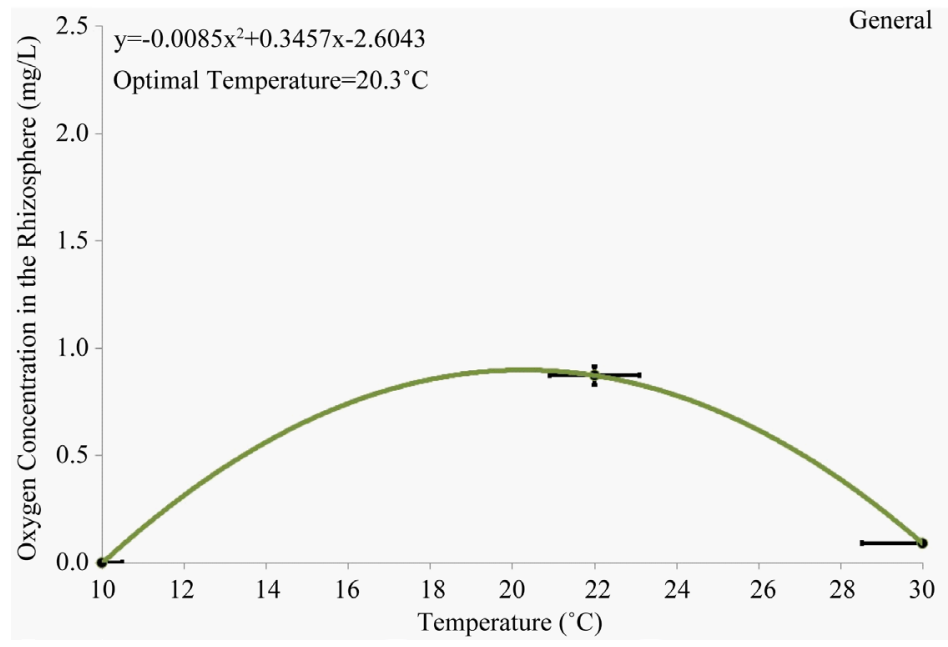

Figure 3. The influence of temperature on oxygen concentration in the rhizosphere. Vertical and horizontal bars represent standard error. 


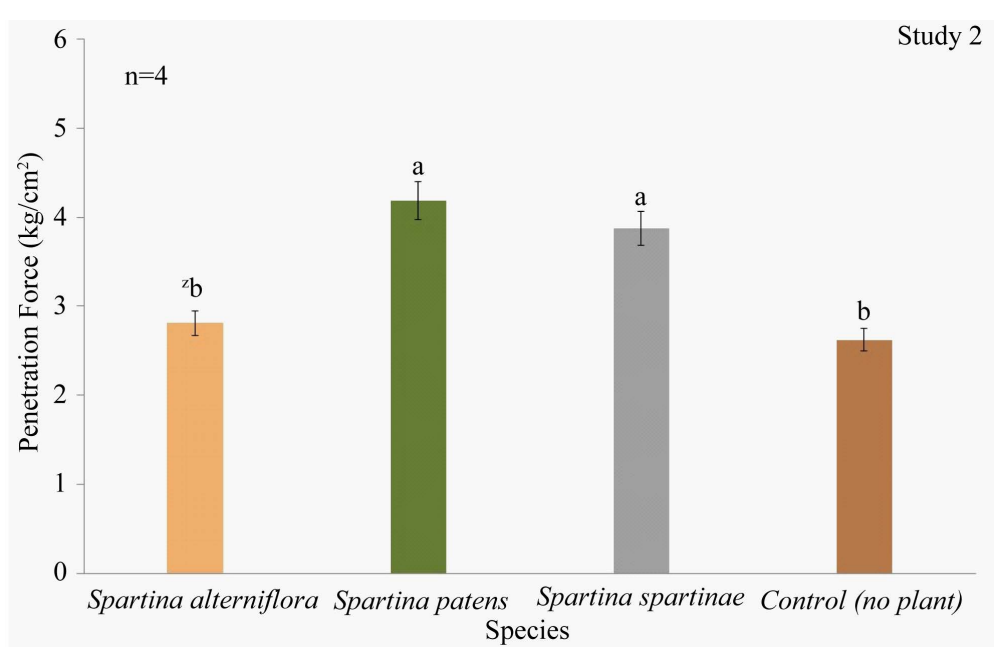

Figure 4. The influence of plant species on the force to penetrate wet soil. ${ }^{\mathrm{z}}$ Means with the same letter are not significantly different at the 0.05 level Vertical bars represent standard error.

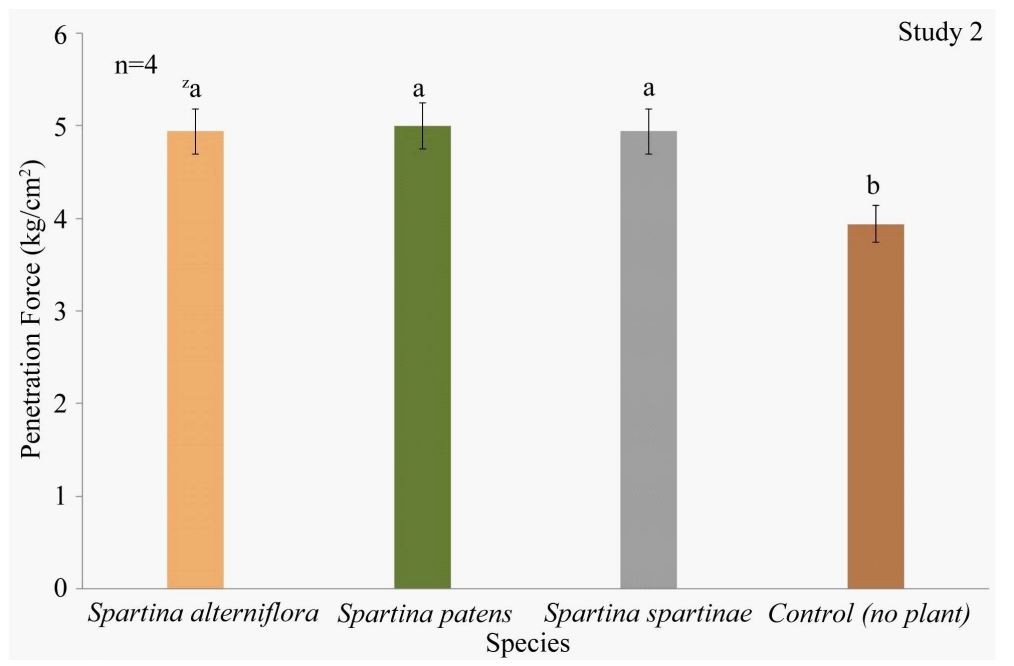

Figure 5. The influence of plant species on the force to penetrate dry soil. ${ }^{\mathrm{z}}$ Means with the same letter are not significantly different at the 0.05 level Vertical bars represent standard error.

penetration force and the least subsidence.

Plants require essential nutrients for normal plant growth. Spartina alterniflora carbon accumulation was 2\% less than S. patens and S. spartinae. Leaf tissue N was greater in S. alterniflora compared to S. patens and S. spartinae (Table 1). Spartina patens and spartinae $\mathrm{C} / \mathrm{N}$ ratio was greater than that of S. alterniflora. Phosphorus and $\mathrm{K}$ are two additional fertilizer nutrients commonly found in offsite run-off. Results indicated that leaf tissue levels were highest in S. alterniflora $>$ S. patens $>$ S. spartinae, respectively. Nitrogen, P and K leaf tissue levels of $S$. alterniflora were similar to previous field data published [19]. Osmocote is a nursery fertilizer designed to give luxury nutrient consumption of essential plant nutrients during a specific production cycle. The similarity of leaf tissue nutrient levels in this study to previously published field research confirms that nutrient loads in marshes can uptake high nutrient levels and Spartina alterniflora can adapt and uptake high fertilizer nutrient levels. Calcium and Mg tissue levels of Spartina spartinae were greater than S. alterniflora. Sulfur leaf tissue content was greatest in Spartina alterniflora. Copper, Mo, and $\mathrm{Zn}$ were significantly greatest in Spartina alterniflora plants. Manganese was greatest in Spartina patens. Iron and B were similar for all plant species. Excessive Fe and Mn uptake from waterlogged and flooded soils can occur if a plant is incapable of excluding excessive 


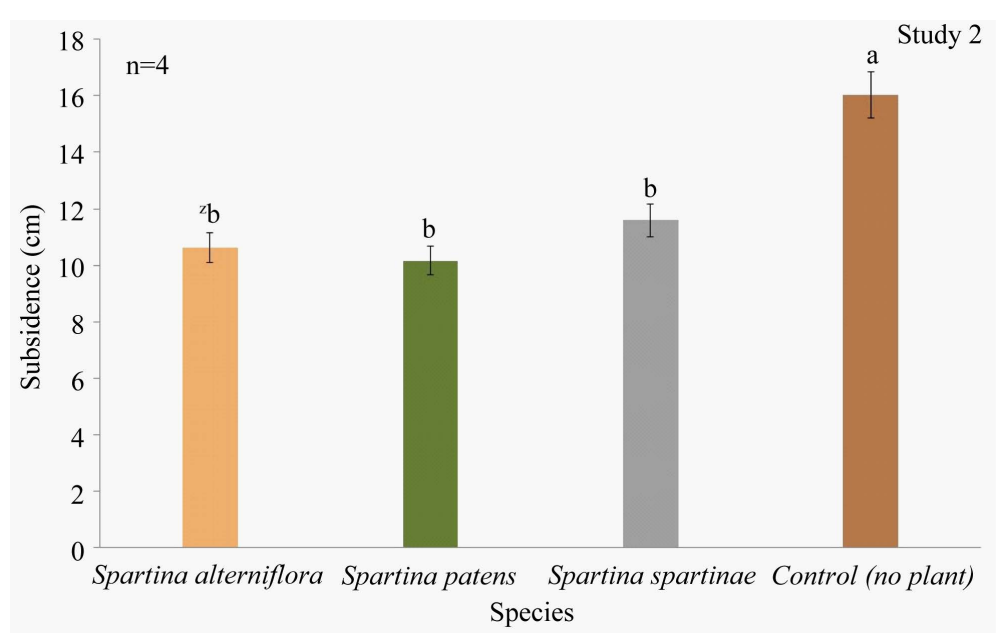

Figure 6. The influence of plant species on subsidence. ${ }^{\mathrm{z}}$ Means with the same letter are not significantly different at the 0.05 level Vertical bars represent standard error.

Table 1. Average macronutrient and micronutrient leaf content of Spartina species.

\begin{tabular}{|c|c|c|c|c|c|c|c|c|c|c|c|c|c|c|}
\hline Species $^{\mathrm{Z}}$ & $\mathrm{C}$ & $\mathrm{N}$ & $\mathrm{C} / \mathrm{N}$ & $\mathrm{P}$ & K & $\mathrm{Ca}$ & $\mathrm{Mg}$ & S & B & $\mathrm{Cu}$ & $\mathrm{Fe}$ & $\mathrm{Mn}$ & Mo & $\mathrm{Zn}$ \\
\hline & \multicolumn{8}{|c|}{ 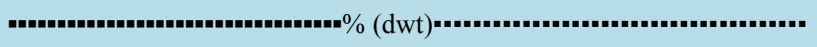 } & \multicolumn{6}{|c|}{ 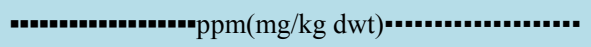 } \\
\hline SA & $43 b^{z}$ & $2.1 \mathrm{a}$ & $21 b$ & $0.32 \mathrm{a}$ & $0.32 \mathrm{a}$ & $0.09 \mathrm{~b}$ & $0.08 \mathrm{~b}$ & $0.3 \mathrm{a}$ & $9.0 \mathrm{a}$ & $8.5 \mathrm{a}$ & $161 \mathrm{a}$ & $113 \mathrm{~b}$ & $5.2 \mathrm{a}$ & $52 \mathrm{a}$ \\
\hline SP & $45 \mathrm{a}$ & $1.8 \mathrm{~b}$ & $25 \mathrm{a}$ & $0.23 \mathrm{~b}$ & $0.23 \mathrm{~b}$ & $0.16 \mathrm{ab}$ & $0.09 \mathrm{~b}$ & $0.2 \mathrm{~b}$ & $7.0 \mathrm{a}$ & $6.1 \mathrm{~b}$ & $160 \mathrm{a}$ & $157 \mathrm{a}$ & $3.3 \mathrm{~b}$ & $25 \mathrm{~b}$ \\
\hline SS & $45 \mathrm{a}$ & $1.7 \mathrm{~b}$ & $27 \mathrm{a}$ & $0.18 \mathrm{c}$ & $0.18 \mathrm{c}$ & $0.21 \mathrm{a}$ & $0.16 \mathrm{a}$ & $0.2 \mathrm{~b}$ & $7.0 \mathrm{a}$ & $5.3 \mathrm{~b}$ & $162 \mathrm{a}$ & $120 \mathrm{~b}$ & $2.6 \mathrm{~b}$ & $24 \mathrm{~b}$ \\
\hline
\end{tabular}

${ }^{\mathrm{z}}$ Means followed by the same letter within columns are not significantly different from each other at the 0.05 level. $\mathrm{SA}=$ Spartina alterniflora; $\mathrm{SP}=$ Spartina patens; $\mathrm{SS}=$ Spartina spartinae.

availability in reduced soils. Plant adaptations to coastal flooding may include the exclusion of excessive Fe and Mn uptake. Although all plants resulted in healthy growth, previous research has indicated that Spartina plants require very low fertility. The fertilizer rate supplied in this research does suggest that native stands on the coast can actually uptake excess nutrient pollution in the Gulf of Mexico, helping to reduce nutrient loads. These plants are versatile capable of withstanding constant water logging, temporary submergence and/or flooding and excess nutrients. Modest levels of DO were diffused in this experiment; however these plants were grown in a restricted environment with no tidal movement, high fertility and no perimeter water surface exposed for oxygen diffusion. These conditions exemplify the capacity of this Spartina sp. to adapt to coastal conditions and survive a harsh environment.

\section{Conclusion}

This experiment was conducted to determine the influence of temperature on the dissolved oxygen in water, subsidence, and penetration force of Spartina alterniflora, Spartina patens, Spartina spartinae, and no plants. After twenty-seven occurrences of measuring dissolved oxygen at specified temperatures of all treatments, there was a clear relationship among species and dissolved oxygen, subsidence, and penetration force. It has been concluded that temperature also influences dissolved oxygen, and as temperature remains around $20^{\circ} \mathrm{C}$, the species create the greatest amount of oxygen. As grasses are exposed to temperatures outside this optimal range, such as $10^{\circ} \mathrm{C}$ and $30^{\circ} \mathrm{C}$, the amount of dissolved oxygen they diffuse in water begins to dwindle. Spartina alterniflora and the control group diffused the most oxygen in water at $30^{\circ} \mathrm{C}$, the control diffused the most oxygen in water at $22^{\circ} \mathrm{C}$, and all the species produced the same amount of oxygen. These plants, regardless of species, did not produce as much oxygen at temperatures far from $22^{\circ} \mathrm{C}$, but at this temperature, they produced similar amounts of oxygen. The control produced the most oxygen at $22^{\circ} \mathrm{C}$, but the subsidence and penetration experiments showed 
that the vegetation slowed down subsidence and its soil required a greater force to penetrate. These benefits outweigh the larger production of oxygen by the control, so vegetation proves to be a crucial factor along the Gulf Coast.

\section{Application to Society}

Determining the amelioration of different Spartina grasses or the absence of vegetation on marshes will provide an improved understanding of marsh grass selection and the overall costal environment. Erosion, subsidence, and salt-water intrusion, serious problems not only in Louisiana, but across the globe, continuously take a toll on land, vegetation, and habitats. With erosion comes loss of land and with land-loss comes habitat damage and economic decline. Marsh grasses and trees continuously protect vulnerable islands from dangerous storms and inauspicious salt water intrusion. These grasses can lessen the force of strong hits and slow salt water intrusion by tolerating some salinity. Without these crucial plants, environments continue to decline due to lack of protection. Even with plants, many marshes are deteriorating due to hypoxia, or lack of oxygen. An environment without oxygen cannot support life which is needed to prolong the lives of marshes. No oxygen means vegetation and habitat loss which then leads to vulnerability and later open-water areas. An effective way to combat these noxious forces is marsh grasses because they provide shelter, protect inward land against the daily ebb and flow of water, commonly reduce salt water intrusion, prevent subsidence, and produce oxygen. This oxygen supplies organisms with necessary nutrients, and plants produce it as a bi-product of photosynthesis. With the data collected in the experiment, it does show a slight relationship between species and dissolved oxygen in water, as well as penetration force of the soil surface and subsidence. This valuable information can be used to effectively select marsh grasses that resist erosion and sinking and protect the marshes as well as possible. The barrier islands and marshes are essential to main-shore protection. Vegetation can slow forces of erosion, subsidence, and hypoxia on the Louisiana coast. The management of Louisiana's coastline will require a balance between economic demands and preservation of sensitive coastal environmental resources.

\section{References}

[1] Coastal Protection and Restoration Authority (CPRA) (2013) Fiscal Year 2012 Annual Plan: Integrated Ecosystem Restoration and Hurricane Protection in Coastal Louisiana. Coastal Protection and Restoration Authority of Louisiana, Baton Rouge.

[2] Spearing, D. (1995) Roadside Geology. Mountain Press Publishing Company, Missoula, 1-202.

[3] Coastal Erosion: Facts and Figures (2012) Restore or Retreat, Inc., Thibodaux. http://www.restoreorretreat.org/la erosion facts.php.

[4] United States Geological Survey (USGS) (2009) Isle Derniere. Map. National Public Radio. http://216.35.221.84/templates/story/story.php?storyId=104723428

[5] Waller, R.M. (2013) Land Subsidence. In: USGS: Science for a Changing World. http://ga.water.usgs.gov/edu/earthgwlandsubside.html

[6] Penland, S., Williams, S.J., Davis, D.W., Sallenger Jr., A.H. and Groat, C.G. (1992) Barrier Island Erosion and Wetland Loss in Louisiana. In: Williams, S.J., Penland, S. and Richeson, D., Eds., Euler's Gem: The Polyhedron Formula and the Birth of Topology, Princeton University Press, Princeton, 124-127.

[7] Maygarden, D. (2012) Barrier Islands: Educators' Guide. Barataria-Terrebone National Estuary Program. http://lacoast.gov/new/Ed/Curriculum/BarrierIslandEducatorsGuide.pdf

[8] Sallenger Jr., A.H., Eds. (1992) Louisiana Barrier Island Erosion Study-Atlas of Barrier Shoreline Changes in Louisiana from 1853 to 1989. U.S. Geological Survey Miscellaneous Investigations Series I-2150-A, 2-7.

[9] Wold, A. (2013) Dead Zone Smaller than Predicted. The Advocate, 1A, 4A.

[10] Blanchard, P. (2013) Wetlands Loss = Fisheries Loss. Barataria-Terrebone National Estuary Program, Baton Rouge.

[11] Jones Jr., R.R. (1973) Utilization of Louisiana Estuarine Sediments as a Source of Nutrition for the Brown Shrimp, Penaeusaztecus. Ph.D. Dissertation, Louisiana State University, Baton Rouge.

[12] Bush, T. (2008) Plant Fact Sheet: Smooth Cordgrass. United States Department of Agriculture and Natural Resource Conservation Service, Washington DC. http://plants.usda.gov/factsheet/pdf/fs_spal.pdf

[13] Lloyd-Reilley, J. (2003) Plant Fact Sheet: Gulf Cordgrass. United States Department of Agriculture and Natural Resource Conservation Service, Washington DC. http://plants.usda.gov/factsheet/pdf/fs_spsp.pdf 
[14] Bush, T. (2008) Plant Fact Sheet: Saltmeadow Cordgrass. United States Department of Agriculture and Natural Resource Conservation Service, Washington DC. http://plants.usda.gov/factsheet/pdf/fs_sppa.pdf

[15] Rhodes, B. and Robicheaux, E. (2013) Edens on the Edge [DVD]. Louisiana Sea Grant College Program, Baton Rouge. Available from Communications, Louisiana Sea Grant Building, Baton Rouge, LA 70803.

[16] Sallenger, A. (2009) Island in a Storm. Public Affairs, New York, 1-220.

[17] USGS (2006) Louisiana Department of Natural Resources, and Pontchartrain Institute for Environmental Sciences. 1887 vs. 1934. Map. Louisiana Barrier Islands Comprehensive Monitoring Program. http://www.ladigitalcoast.uno.edu/PDFs/ider1887-2005_shrlnchng.pdf

[18] U.S. Department of Agriculture (2012) Soil Subsidence. http://www.nrcs.usda.gov/Internet/FSE_DOCUMENTS/stelprdb1187276.pdf

[19] Hester, M., Willis, J. and Alleman, L. (2009) Continued Monitoring of the Bucktown Created Marsh: 2008 Negative and Edaphic Characterization and Effects of the 2008 Bonnet Carre Opening on Nutrient Status of Sediment and Plant Tissue (Report for the Coastal Sustainability Program Lake Pontchartrain Basin Foundation). Coastal Plant Ecology Laboratory, Department of Biology, University of Louisiana at Lafayette, LA 70504. 